\title{
Polyclonal B cell activation in ankylosing spondylitis
}

Paola Barbieri, Ignazio Olivieri, Gioia Benedettini, Paola Marelli, Maria Laura Ciompi, Giampiero Pasero, Mario Campa

\begin{abstract}
The peripheral blood lymphocyte response of patients with ankylosing spondylitis (AS) to several polyclonal B cell activators was investigated. No differences were found in the reactivity to pokeweed mitogen and protein $A$ between patients and controls; in contrast, the peripheral blood lymphocyte response to Staphylococcus aureus strain Cowan I (SAC) was significantly higher in patients with AS than in controls. This responsiveness was not influenced either by the presence of the HLAB27 antigen or by environmental factors or associated diseases, and it was higher in patients with active AS than in those with inactive disease. The percentage of circulating B cells was normal. The responses to $T$ cell mitogens and the percentages of $T$ cell subpopulations were similar in patients and in controls. The peripheral blood lymphocyte hyperactivity of patients with AS to SAC was associated with an increased in vitro production of immunoglobulins.
\end{abstract}

Despite its close association with HLA-B27 of the major histocompatibility complex, ankylosing spondylitis (AS) remains a disease of unknown cause. It has been suggested by two different groups of researchers that Klebsiella pneumoniae may have a role in the pathogenesis of AS in B27 positive subjects. ${ }^{12}$ Although the evidence for an association between klebsiella and AS is conflicting, ${ }^{3}$ it is generally agreed that environmental factor(s), in addition to predisposing genetic determinants, may be important in the pathogenesis of the disease. ${ }^{4}$

Some authors have postulated a pathogenetic role for other parasites, such as Streptococcus faecalis, Escherichia coli, Clostridium perfringens, and Epstein-Barr virus. ${ }^{5} 6$ The common denominator of these micro-organisms is their ability to behave as polyclonal $B$ cell activators for mouse and human lymphocytes. ${ }^{7-10}$

Increased concentrations of serum immunoglobulins in patients with AS have been considered an expression of B cell hyperactivity. Furthermore, increased proportions of peripheral B lymphocytes ${ }^{11}$ and immunoblasts ${ }^{12}$ have been reported in AS.

In this investigation the in vitro response of lymphocytes to several polyclonal B cell activators was studied as an expression of polyclonal $B$ cell activation. The results show an increased proliferative and secretive response of lymphocytes from patients with AS to Staphylococcus aureus strain Cowan I (SAC), a strong polyclonal B cell activator. ${ }^{13}$

\section{Patients and methods PATIENTS}

Four groups of subjects were studied. Group A: 40 patients (31 male, nine female) with AS according to the Rome and New York criteria, with an average age of 40.6 (SD 12.1) years; 35 patients were HLA-B27 positive. Group B: 10 patients (four male, six female) with AS associated with other diseases (seven with psoriatic arthritis, and one patient each with reactive arthritis, Reiter's syndrome, and ulcerative colitis), with an average age of $43 \cdot 1(8 \cdot 1)$ years and mean disease duration of $7 \cdot 2(2 \cdot 3)$ years; four patients carried HLA-B27. Group C: 25 relatives and cohabitants of group A patients $(14$ male, 11 female); 10 were HLA-B27 positive. To detect previously undiagnosed AS each member of group $\mathrm{C}$ answered a questionnaire about back pain and associated symptoms; those who had a significant history received sacroiliac joint $x$ rays. Group D: 40 healthy subjects matched for age and sex; all HLA-B27 negative.

Nineteen patients from group A were considered active because they experienced significant pain, active peripheral arthritis, morning stiffness, or acute anterior uveitis. ${ }^{14}$ The subjects took no drugs in the 24 hours before the study.

\section{PREPARATION OF LYMPHOCYTES}

Peripheral venous blood was collected with heparin; mononuclear cells were isolated by centrifugation on a Ficoll-Hypaque (Eurobio; Paris) density gradient.

MITOGEN RESPONSE

Peripheral blood lymphocytes were suspended in RPMI 1640 supplemented with $10 \%$ fetal calf serum (Flow Laboratories, Irvine, UK), 1\% Lglutamine (200 mmol/l), streptomycin (200 $\mu \mathrm{g} / \mathrm{ml})$, and penicillin $(200 \mathrm{IU} / \mathrm{ml})$. Triplicate cultures were set up in tissue culture microplates (Microtest II Falcon, California, USA) using $2 \times 10^{5}$ cells $/ 0.2 \mathrm{ml}$ in each well. After 72 hours at $37^{\circ} \mathrm{C}$ in a $5 \% \mathrm{CO}_{2}$ atmosphere the cultures were pulsed with tritiated thymidine (18.5 kBq/well; Radiochemical Centre, Amersham, England). Twenty four hours later the cells were harvested with a Microtiter Dynatech Automash on a glass fibre paper. Cell incorporation of $\left[{ }^{3} \mathrm{H}\right]$ thymidine was counted on a Beckman liquid scintillation counter after addition of scintillation fluid.

PHYTOHAEMAGGLUTININ AND OTHER MITOGENS Phytohaemagglutinin (Difco, Detroit, USA) 
was used at a final concentration of $1 \mu \mathrm{g} / 200 \mu \mathrm{l}$; concanavalin A (Calbiochem, Lucerne, Switzerland) at a final concentration of $3 \mu \mathrm{g} / 200 \mu \mathrm{l}$; pokeweed mitogen (Gibco, Glasgow, UK) at a final dilution of 1:1000; protein A (Pharmacia, Uppsala, Sweden) at a final concentration of 4 $\mu \mathrm{g} / \mu \mathrm{l}$; a heat and formalin treated suspension of SAC was added at a concentration of $6 \times 10^{6}$ bacteria/20 $\mu$ l to each well. ${ }^{15}$

\section{T LYMPHOCYTE SUBPOPULATIONS}

T lymphocyte subpopulations were tested ${ }^{16}$ by a cytotoxicity test using the monoclonal antibodies OKT3, OKT4, and OKT8 (Ortho Pharmaceuticals Co, New Jersey, USA).

\section{B LYMPHOCYTES}

Peripheral blood lymphocytes were incubated in serum free RPMI 1640 at $37^{\circ} \mathrm{C}$ for 30 minutes and washed three times at $37^{\circ} \mathrm{C}$. Fluorescein isothiocyanate conjugated $F\left(a^{\prime}\right)_{2}$ goat IgG was used against human light and heavy chains (Behring Institute, Italy). After the last washing the cell pellet was resuspended in $50 \mu \mathrm{l}$ of the mixed fluorescein isothiocyanate conjugated reagents; the cells were then incubated at $4^{\circ} \mathrm{C}$ for 30 minutes at the optimal dilution and were thereafter washed twice in phosphate buffered saline (PBS) with $0 \cdot 1 \mathrm{~g} / \mathrm{l}$ bovine serum albumin. The cells were mounted on a microscope slide under a cover glass and read at $400 \times$ magnification. Interference microscopy was used to identify non-fluorescing cells.

\section{IN VITRO IMMUNOGLOBULIN SYNTHESIS}

Peripheral blood lymphocytes suspended at $2 \times 10^{6}$ cells $/ \mathrm{ml}$ in RPMI 1640 medium, supplemented as for the mitogen response, were cultured in flat bottomed plates (Flow Laboratories, Irvine, UK). Pokeweed mitogen, SAC, or no mitogen was added at the set up of the culture; cells were cultured for seven days at $37^{\circ} \mathrm{C}$ in a $5 \% \mathrm{CO}_{2}$ humidified atmosphere. The supernatants were then separated from the cells after centrifugation for 10 minutes at $400 \mathrm{~g}$, collected, and stored at $4^{\circ} \mathrm{C}$.

\section{MEASUREMENT OF IMMUNOGLOBULIN SECRETION} IN CULTURE SUPERNATANTS

An enzyme linked immunosorbent assay (ELISA) was used to measure secreted IgG, $\operatorname{IgA}$, and IgM in culture supernatants. The wells of the microtitre plates (Flow Laboratories, Irvine, UK) were coated with goat antihuman immunoglobulin serum $\left(\mathrm{F}\left(\mathrm{ab}^{\prime}\right)_{2}\right.$-antihuman IgG, IgGA, IgM; Cappel Laboratories, USA) and stored overnight at $4^{\circ} \mathrm{C}$. The plates were washed three times with PBS-Tween 20, then the supernatants from the lymphocyte cultures were added to the wells; after one hour the plates were washed with PBS-Tween 20 . The bound $\operatorname{IgA}, \operatorname{IgG}$, and $\operatorname{IgM}$ were detected with peroxidase conjugated goat antihuman IgG, IgA, or IgM respectively (Bio-Yeda, Rheovot, Israel). The absorbance at $492 \mathrm{~nm}$ was measured with a Titertek Multiskan (Flow Laboratories,
UK). The amount of class specific immunoglobulin was determined from standard curves obtained from samples with known amounts of human immunoglobulin (IgA, Bio-Yeda, Israel; IgG and IgM, Sigma Chemical Co, St Louis, USA).

\section{STATISTICAL ANALYSIS}

The responses to various mitogens in patients were compared with responses in controls using Wilcoxon's rank sum test; the responses of patients' groups to SAC were compared by the Kruskal-Wallis test.

\section{Results}

MITOGEN RESPONSE

The unstimulated peripheral blood lymphocytes of patients with AS showed a lower thymidine uptake than the peripheral blood lymphocytes in normal controls, but the difference did not reach statistical significance. The response of peripheral blood lymphocytes to phytohaemagglutinin, concanavalin A, pokeweed mitogen, and protein $A$ showed no difference between patients and controls. In contrast, the response to SAC was significantly higher in patients than in controls (table 1).

To investigate the factors that might influence the peripheral blood lymphocyte response to SAC in patients with AS we considered the disease activity, the presence of HLA-B27 antigen, and environmental factors, as well as associated diseases. Table 2 summarises the results. No differences in the response to SAC were found between HLA-B27 positive and negative patients. Furthermore, the SAC response of healthy $B 27$ negative controls did not differ from that of HLA-B27 negative and HLA-B27 positive patients' relatives and family members (table 2).

Table 1: Response of lymphocytes from patients with ankylosing spondylitis and from healthy controls to various mitogens. Results show the mean $(S D)$ counts per minute

\begin{tabular}{|c|c|c|}
\hline Mitogens & Patients & Controls \\
\hline $\begin{array}{l}\text { None } \\
\text { PWM } \\
\text { Protein A } \\
\text { SACt }\end{array}$ & 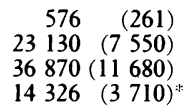 & 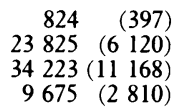 \\
\hline
\end{tabular}

" $<<0.01$ (data from patients and controls were compared for each mitogen)

+PWM = pokeweed mitogen; $\mathrm{SAC}=$ Staphylococcus aureus strain Cowan I.

Table 2: Factors influencing lymphocyte response of patients with ankylosing spondylitis (AS) to Staphylococcus aureus Cowan

\begin{tabular}{lll}
\hline Subjects & HLA-B27 & $\begin{array}{c}\text { Mean response (SD) } \\
(c p m)\end{array}$ \\
\hline Patients with AS & + & $13934(2015)$ \\
Patients with AS & - & $12391(3021)$ \\
AS+other diseases & + & $9215(2605)$ \\
AS+ other diseases & - & $9110(2515)$ \\
Relatives & + & $8715(1810)$ \\
Relatives & - & $9115(2590)$ \\
Family members & - & $9510(1920)$ \\
Healthy controls & $9675(2810)$ \\
Patients with active AS & $16970(2783)$ \\
Patients with inactive AS & $8770(1929)$ \\
\hline p $<0.01$, patients with active AS $v$ those with inactive AS.
\end{tabular}


Table 3: In vitro immunoglobulin production ( $\mathrm{ng} / \mathrm{ml}$ ) by lymphocytes from patients with ankylosing spondylitis and from healthy controls. Results are given as mean (SD)

\begin{tabular}{|c|c|c|c|}
\hline Stimulation & Ig classes & Patients & Controls \\
\hline None & $\begin{array}{l}\mathrm{G} \\
\mathrm{A} \\
\mathrm{M}\end{array}$ & $\begin{array}{ll}229 & (88) \\
141 & (56) \\
139 & (68)\end{array}$ & $\begin{array}{rr}120 & (60) \\
80 & (41) \\
110 & (55)\end{array}$ \\
\hline PWM† & $\begin{array}{l}\mathrm{G} \\
\mathrm{A} \\
\mathrm{M}\end{array}$ & $\begin{array}{r}1200(670) \\
380(210) \\
750(187)\end{array}$ & $\begin{array}{r}1187(529) \\
420(160) \\
650(201)\end{array}$ \\
\hline SAC $†$ & $\begin{array}{l}\mathrm{G} \\
\mathrm{A} \\
\mathrm{M}\end{array}$ & $\begin{array}{l}970(250) \\
450(132) \\
850(202)^{*}\end{array}$ & $\begin{array}{l}810(270) \\
380(140) \\
610(150)\end{array}$ \\
\hline
\end{tabular}

In the 10 patients with AS who also had other diseases (group B) we found no difference in SAC response in comparison with the healthy controls.

Those patients with active disease showed a significantly higher response to SAC than patients with inactive disease and healthy controls. Moreover, patients with active disease showed a slightly increased percentage of circulating B lymphocytes.

The percentage of OKT3+, OKT4+, and OKT8+ cells and the OKT4/OKT8 ratio showed no differences between patients and healthy controls.

\section{IMMUNOGLOBULIN SYNTHESIS}

The IgG concentrations in the supernatants of patient peripheral blood lymphocyte cultures were similar to those found in the supernatants of controls even when the peripheral blood lymphocytes were stimulated with pokeweed mitogen (table 3 ). In contrast, stimulation by SAC caused a higher production of immunoglobulin by patients' peripheral blood lymphocytes than by those of controls, but only $\operatorname{IgM}$ concentrations reached statistical significance (table 3).

\section{Discussion}

These results show that the peripheral blood lymphocyte response to SAC by patients with AS is higher than that of healthy family members of patients with AS and that of HLAB27 positive or negative healthy subjects. This hyperresponsiveness was found to be associated with the disease activity. Moreover, peripheral blood lymphocytes from all patients with AS showed an increased in vitro production of immunoglobulin only after SAC stimulation. In addition, the percentage of $T$ cell subpopulations was similar in patients and in controls.

The responsiveness to SAC has already been studied in association with other rheumatic diseases. An impaired peripheral blood lymphocyte response to peptidoglycan from Staphylococcus aureus and in vitro production of rheumatoid factor were shown in patients with rheumatoid arthritis and in healthy subjects respectively. ${ }^{17} 18$ Furthermore, an impaired response to SAC was shown in systemic lupus erythematosus and in Behçet's syndrome. ${ }^{19} 20$
The main point raised by our study is that the increased peripheral blood lymphocyte responsiveness to SAC in patients with AS seems to be related to the disease activity. This observation is in agreement with the findings reported by others showing increased concentrations of immunoglobulin during the period of disease activity. ${ }^{21}$

The presence of the HLA-B27 antigen does not seem to influence the peripheral blood lymphocyte responsiveness to SAC, though this observation is not in keeping with other reports about expression of immune reactivity.22 23 Similarly, environmental factors do not appear to have a role in the response to SAC as no differences were found between patients and their relatives and family members.

The lack of an association between lymphocyte responsiveness of patients with AS and SAC, protein $A$, and pokeweed mitogen may be explained by the fact that pokeweed mitogen and protein $A$ are $T$ cell dependent polyclonal $B$ cell activators, whereas SAC is a $\mathrm{T}$ cell independent B cell activator. ${ }^{1324}$

This finding focused our interest on B cell function. The data about $B$ cell involvement in AS are controversial; increased proportions of B lymphocytes $^{11}$ and immunoblasts ${ }^{12}$ have been reported, but there is some controversy about the technical procedures that were used. ${ }^{11} 1225$ We used $F\left(a^{\prime}\right)_{2}$ reagents and found an increased number of circulating $B$ cells in some of our patients.

Increased concentrations of IgG in the serum of patients with AS have been considered to be a sign of polyclonal B cell activation. ${ }^{26}$ Yersinia enterocolitica and SAC have been reported to lead to an increased in vitro production of $\mathrm{IgG}$, whereas pokeweed mitogen induces low concentrations of IgM; increased concentrations of $\operatorname{IgA}$ have been found in unstimulated cultures. ${ }^{27} 28$ Our data partially agree with these reports. Indeed, we found a slight increase in the spontaneous production of immunoglobulin in patients with AS, even though the response reached significance only when peripheral blood lymphocytes were stimulated with SAC.

In conclusion, the possibility exists that under particular circumstances, which remain to be clarified, the introduction of a polyclonal $B$ cell activator into an organism may alter the host immunoreactivity.

1 Edmonds J, Geczy A F, Sullivan J S, Prendergast J K, Upfold L I, Bashir H V. Enteric bacteria and HLA-B27 associated cell surface modification in patients with seroartive spondarthritis. Br 7 Rheumatol 1983; 22 (suppl): 75-82.

2 Ebringer A, Baines M, Ptaszynska T. Spondyloarthritis, uveitis, HLA-B27 and klebsiella. Immunol Rev 1985; 86: 101-16.

3 Kinsella D T, Fritzler $M$ J, Lewkonia R M. Normal antiklebsiella lymphocytotoxicity in ankylosing spondyltis. Arhritis Rheum 1986; 29: 358-62.

Arthritis Rheum 1986; 29: $358-62$.
4 Terasaki P I, Yu D T Y. Regarding the ankylosing Terasaki P I, Yu D T Y. Regarding the ankylosing 1987; 30: 353-4.

5 Prendergast J K, Sullivan J S, Geczy A F, et al. Possible role of enteric organisms in the pathogenesis of ankylosing spondylitis and other seronegative arthropathies. Infect Immun 1983; 41: 935-41.

6 Robinson S, Panayi G. Deficient control of in vitro EpsteinBarr virus infection in patients with ankylosing spondylitis. Ann Rheum Dis 1986; 45: 974-7.

7 Campa M. Bacterial infections, immunity and reactive arthritis. Clin Exp Rheumatol 1983; 1: 189-93.

8 Falcone G, Campa M. Bacterial interference with the immune 
response. In: O'Grady F, Smith $\mathrm{H}$, eds. Microbial perturbation of host defences. London: Academic Press, 1981: tion 210 .

9 Rasanen L, Letho M, Jokinen I, Leinikki P. Polyclonal antibody formation of human lymphocytes to bacterial components. Immunology 1986; 58: 577-81.

10 Primi D, Smith C I E, Hammarstrom L, Moller G. Polyclonal B cell activators induce immunological response to autologous serum proteins. Cell Immunol 1977; 34: 367-8.

11 Byrom N A, Campbell M A, Hobbs J R, et al. T and B lymphocytes in patients with acute anterior uveitis and ankylosing spondylitis, and their household contacts. Lancet 1979; ii: $601-3$.

12 Eghtedari A A, Davis P, Bacon P A. Immunological reactivity in ankylosing spondylitis. Circulating immunoblasts, autoantibodies and immunoglobulins. Ann Rheum Dis 1976; 35: 155-7.

13 Romagnani S, Amadori A, Giudizi M G, Biagiotti R, Maggi E, Ricci $M$. Different mitogenic activity of soluble and insoluble staphyloccoccal protein A (SPA). Immunology 1978; 35: 471-8.

14 Sheehan N J, Slavin B M, Donovan M P, Mount J N, Mathews J A. Lack of correlation between clinical disease activity and erythrocyte sedimentation rate, acute phase proteins or protease inhibitors in ankylosing spondylitis. $\mathrm{Br}$ proteins or protease inhibitors 1986; 25: $171-4$.

15 Arvidson S, Holme T, Wadström T. Influence of cultivation conditions on the production of extracellular protein by Staphylococcus aureus. Acta Pathologica et Microbiologica Staphylococcus aureus. Acta Pathologica et Microbiologica
Scandinavica. Section B. Microbiology and Immunology 1971; 79: 391-405.

16 Barbieri P, Benedettini G, Ferri C, Campa M, Bombardieri S. Lymphocyte subpopulations in essential mixed cryoglobulinemia. F Rheumatol 1986; 13: 108-12.

17 Pardo I, Carafa C, Dziarski R, Levinson A I. Analysis of in vivo polyclonal $B$ cell differentiation responses to bacterial peptidoglycan and pokeweed mitogen in rheumatoid arthritis. Clin Exp Immunol 1984; 56: 253-62.

18 Levy R J, Park H, Tar L, Levinson A I. Bacterial peptidoglycan induces in vitro rheumatoid factor production by lymphocytes of healthy subjects. Clin Exp Immunol 1986; 64: 311-7.

19 Sawada S, Amaki S, Takei M, Karasaki M, Amaki I. Impaired B cell proliferation by Staphylococcus aureus Cowan 1 in patients with systemic lupus erythematosus. Arthritis Rheum 1985; 28: 1008-15.

20 Suzuki N, Sakane T, Ueda Y, Tsunematsu T. Abnormal B cell function in patients with Behçet's disease. Arthritis Rheum 1986; 29: 212-9.

21 Sheldon $P$. Specific cell-mediated response to bacterial antigens and clinical correlations in reactive arthritis, Reiter's syndrome and ankylosing spondylitis. Immunol Rev 1985; 86: 5-25.

22 Trull A, Ebringer A, Panayi G, Ebringer R, James D C O. HLA B27 and the immune response to enterobacterial antigens in ankylosing spondylitis. Clin Exp Immunol 1984; 55: $74-7$.

23 Christiansen F T, Hawkins B R, Dawkins R L. Immune function in ankylosing spondylitis and their relatives: function in ankylosing spondylitis and their relatives: 33: $270-5$.

24 Falkoff R J F, Zhu L P, Fauci A S. Separate signals for human $B$ cell proliferation and differentiation in response to Staphylococcus aureus: evidence for a two signal model of B-cell activation. F Immunol 1982; 129: 97-102.

25 Fann T P, Clements P J, Yu D T J, Opelz G, Bluestone R. Lymphocyte abnormalities in ankylosing spondylitis. Ann Rheum Dis 1977; 36: 471-3.

26 Veys E M, van Laere M. Serum IgG, IgM and IgA levels in ankylosing spondylitis. Ann Rheum Dis 1973; 32: 493-6.

27 Vuento R, Eskola J, Leino R, Koskimies S, Viander M. IgM, IgG and IgA synthesis in vitro in persons suffering from IgG and IgA synthesis in vitro in persons suffering from yersinia arthritis and in patients with
Ann Rheum Dis 1984; 43: 186-91.

28 Warmold A, van den Wall Bake L, Peeters A J, et al. Immunoglobulin synthesis by peripheral blood lymphocytes in patients with ankylosing spondylitis. $\mathcal{f}$ Rheumatol 1988 ; 15: $1410-4$. 